Article

\title{
Fostering Sustainability through Ecosystems for Renewable Energy in India
}

\section{Gita Surie}

Robert B. Willumstad School of Business, Adelphi University, One South Avenue, Garden City, NY 11530, USA; Email: surie@adelphi.edu

\begin{abstract}
Background: This paper focuses on promoting the sustainability of renewable energy ecosystems to ensure socio-economic development. This is critical for emerging economies where rising demand for energy is likely to deplete resources rapidly. It views industrial ecosystems organized around product/material supply chains or in defined geographies as analogous to natural ecosystems. It focuses on renewable energy for rural populations-a special case of industrial ecosystems-in developing countries such as India. Studying this sector is important because: (1) access to energy is a major problem for bottom of the pyramid populations; and, (2) shifting to renewable energy can improve sustainability and inclusive growth.
\end{abstract}

Methods: Case study methods are used to study the renewable energy sector in India. A conceptual framework drawing on various literatures streams (ecological and industrial ecosystems, inclusive growth, entrepreneurship and social entrepreneurship, and renewable energy) is presented to provide insights on how rural renewable energy ecosystems can promote inclusive growth together with environmental and socioeconomic sustainability. Data are drawn from cases on renewable energy in India.

Results: Case data support the framework. Findings indicate that ensuring sustainability requires designing the ecosystem for resilience by facilitating collaboration across diverse types of players. Additionally, stimulating innovation and generating livelihoods by nurturing entrepreneurship are critical for achieving environmental and socioeconomic sustainability.

Conclusions: This paper extends research on industrial ecosystems and sustainability. It provides insights on how renewable energy ecosystems can promote sustainable socio-economic development for the bottom of the pyramid, an under-researched area. Limited data could be overcome through future large sample studies. Results from these cases can provide insights for government policy makers and businesses on how to establish new sustainable ecosystems for sunrise industries in developing and industrialized countries.
Copyright (c) 2020 by the author(s). Licensee Hapres, London, United Kingdom. This is an open access article distributed under the terms and conditions of Creative Commons Attribution $\underline{4.0 \text { International License. }}$ 
KEYWORDS: sustainability; renewable energy; industrial ecosystems; innovation; India

\section{INTRODUCTION \& BACKGROUND}

\section{Introduction}

It is well accepted that it is imperative to take the natural environment into account and eschew reliance on excessive and non-sustainable exploitation of natural resources such as fossil fuels to ensure the health of our planet and resources for future generations [1,2]. Moreover, researchers and policy makers have suggested that economic growth should be decoupled from natural resource use to achieve sustainable development [3]. However, reducing the carbon footprint via clean energy from renewable sources [4] requires a transition to new technologies and new business models and corresponding social change to displace currently entrenched carbon-based systems [5].

Over the past decade, emerging economies such as China, India and Brazil have increased investments in renewable energy to reduce reliance on petroleum imports and improve energy self-reliance, reduce environmental degradation and potentially attain global leadership of the renewable energy sector by developing capabilities [6]. Moreover, examining renewable energy ecosystems is especially relevant as the rise of emerging economies has fueled increased demand for electricity and other energy resources. Additionally, the ability to transform waste and residues into energy and upcycled products through innovation to increase the bottom line is appealing $[4,7,8]$.

The UN's (2015) Sustainable Development Goals (SDGs) include providing affordable clean energy, promoting sustainable consumption and production, conserving terrestrial ecosystems and ensuring work and growth [9]. However, globally, 1.06 billion people at the bottom of the pyramid [10] have no electricity and 3 billion people lack clean fuel for cooking [3]. Although the number of people without electricity access fell below 1 billion in 2017, a fall of 97 million compared to 2016, progress is uneven as three-quarters of the 570 million people who gained access since 2011 are concentrated in Asia [11]. Therefore, it is critical to study the renewable energy ecosystems in developing economies.

This paper focuses on renewable energy in India. The renewable energy sector in India is targeted by the Government of India to grow to $175 \mathrm{GW}$ of power by 2022 [6]. India has also made great strides in the past few years in electrifying villages and, according to the Government of India, all villages were electrified in 2018 [12]. However, about 31 million homes are still in the dark. Villages are considered electrified if $10 \%$ of the households and public buildings such as schools and health centers are connected [12]. Despite progress in electrification, problems remain including unreliable electricity supply, inability to pay for electricity, electricity theft and bankrupt state-owned power supply companies. 
Strides have also been made in poverty reduction with the number of people in multi-dimensional poverty dropping from 670 million in 20052006 to 365.55 million in 2016-2017, a reduction of 271 million. Access to basic services has also increased (e.g., $99.45 \%$ of the population has access to basic sanitation as of July, 2019; [13]). Nevertheless, problems remain, including child poverty and hunger, making socio-economic inclusion for bottom of the pyramid populations [10] a key priority of the government.

Increasing access to energy by promoting the adoption of renewable energy is a major opportunity to reduce the burden on the environment. However, ensuring environmental sustainability through renewable energy ecosystems requires establishing their economic viability.

The paper draws on research on sustainability [1,2] and natural ecosystems [14] to provide insights for ecosystems in new industries [15] such as the renewable energy industry and facilitate the adoption of renewable energy in a manner that is environmentally and socioeconomically sustainable $[8,16]$. Industrial systems are viewed as ecosystems with companies occupying different hierarchical trophic levels as in a food web and materials and energy forming metabolic linkages among them [14]. Industrial ecosystems are organized around product and material supply chains or in defined geographies [14,17]. Inter-firm linkages within the ecosystem include shared management of common utilities, infrastructure (e.g., energy, water), common services with resource conservation benefits, and by-product reuse [18]. Moreover, sustainable wealth can potentially be created by relying on technology and innovation to create businesses that regenerate regional resources and are simultaneously economically competitive and socially beneficial [4].

The paper examines the following research question: In what ways can ecosystems for renewable energy be established for bottom of the pyramid populations and promote environmental and socio-economic sustainability [10]? A conceptual framework is presented to suggest how renewable energy ecosystems can be established to promote environmental and socio-economic sustainability. Case study methods [19] are used to study renewable energy for the bottom of the pyramid in India. Case data provide empirical insights drawing on developments in India and indicate that establishing the ecosystem requires generating various types of resources through interactions among diverse players to ensure sustainability, support for entrepreneurship and innovative low cost business models to reach the target population.

India is an important global player in renewable energy. Solar Photovoltaic (PV) was India's largest source of new power capacity for the second year running (2018) [6], and, for the first time, it accounted for more than half of the capacity added during the year. The Indian rooftop market continued to grow rapidly, up about two-thirds during 2018 by one estimate. But total rooftop capacity remained relatively low, reaching as much as a few GW by year's end, a long way from the national target of 40 GW by 2022. The rooftop market continued to consist mainly of large 
commercial and industrial companies, as well as government entities and educational institutions, all seeking to reduce their electricity bills; few residential customers can afford the upfront costs. As in recent years, most of India's newly installed capacity during 2018 was in large-scale installations, with the bulk of this in five states: Karnataka, Rajasthan, Andhra Pradesh, Tamil Nadu and Maharashtra. At least three of these states (Andhra Pradesh, Karnataka and Tamil Nadu) continued to face curtailment challenges, in the range of $10-25 \%$, which resulted in significant losses to project developers (Curtailment refers to a phenomenon where the power-grid operator limits the power output of specific generators. It is only permitted for maintaining grid stability and system safety, as per the Indian Electricity Code and the renewable energy power purchase agreements; unanticipated curtailment can negatively affect the return on investment and project viability). More than $40 \mathrm{GW}$ of additional large-scale solar projects was tendered in India during 2018. However, the gap expanded between tenders issued and auctions completed. Many auctions were cancelled retroactively, and several gigawatts of awarded capacity were annulled during the year. India has set a production target of $175 \mathrm{GW}$ of electricity through renewables by 2022. Additionally, targets for different technologies are as follows: Solar PV and Concentrating Solar Power (CSP) to increase to 100 GW by 2022; 20 million solar lighting systems (to be added cumulatively from 2010 to 2022); wind power to increase to $60 \mathrm{GW}$ by 2022, and bio-power to increase to $10 \mathrm{GW}$ by 2022 [6]. Additionally, investments in renewable power and fuels continued to rise during the period 2008-2018 (see Figure 1 below). Increasing investments in the renewable sector in India and the government of India's emphasis on socio-economic inclusion make it a relevant context for this research.

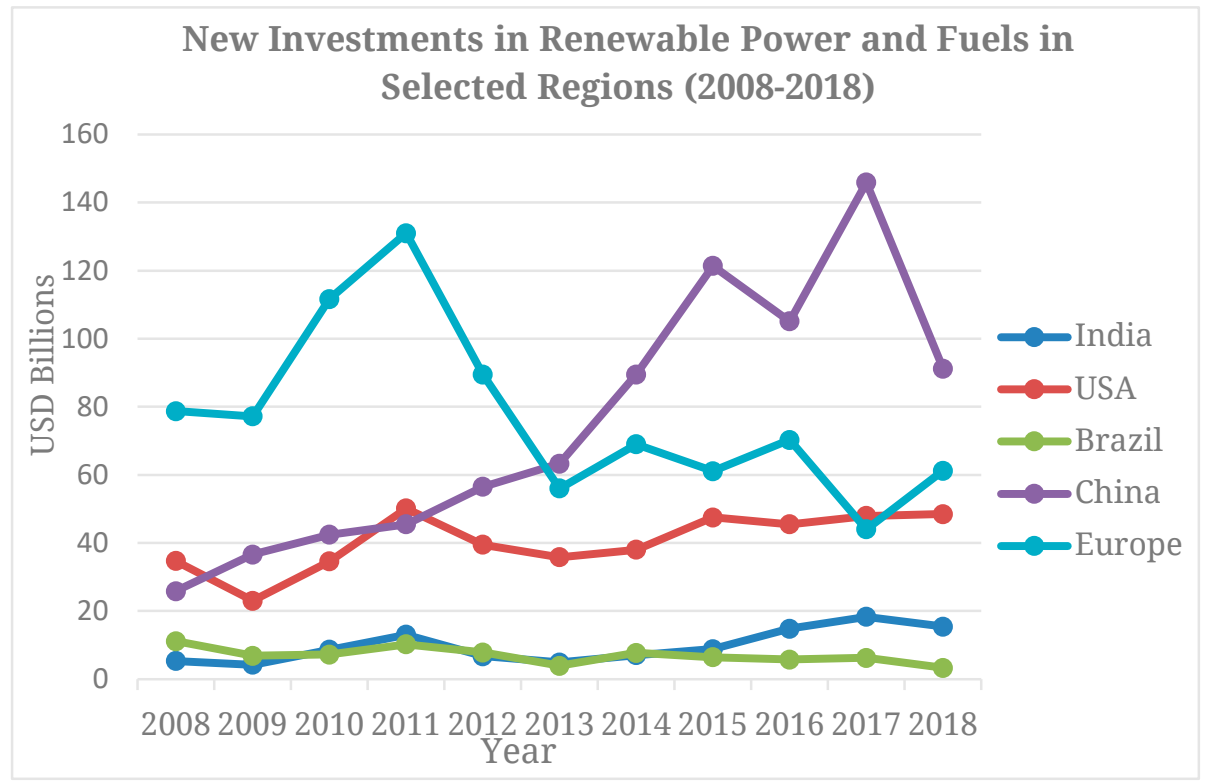

Figure 1. New investment in renewable power and fuels in India (2008-2018). Source: Adapted from REN21 (2019) Global Status Report [6]. 
The next section provides the theoretical literature surveyed for this article followed by a framework that is developed from the literature. The following section describes methods used and results derived from case studies of renewable energy organizations catering to BOP populations that corroborate the framework. The last section provides conclusions and directions for future research.

\section{Background}

\section{Sustainability \& industrial ecosystems}

Discussion of the concept of sustainability dates back to Malthus and was addressed extensively in the 1970s literature on exhaustible resources. The Brundtland report defined sustainable development as "...development that meets the needs of the present without compromising the ability of future generations to meet their own needs" [20]. Thus, sustainable development is economic development that lasts [21], narrowly defined as real Gross Domestic Product per capita or broadened to include indicators of development such as education, health, "quality of life” including human freedom. It is continuously rising, or non-declining consumption per capita or whatever indicator is used to measure development [21]. Pearce and Atkinson's [21,22] measure of sustainability includes (a) strong sustainability, which requires conservation of all exhaustible and renewable resources and does not accept substitutability among different assets; (b) weak sustainability, which requires that the overall stock of capital must not decline. Weak sustainability includes substitution of natural capital with man-made capital so that the constant capital rule is satisfied [21].

While the early literature on sustainability focused on analysing specific environmental innovation processes [23] the technological innovation systems approach (a subset of the national innovation systems literature) considers the whole range of relevant actors including governments, non-governmental organizations (NGOS), research institutes as well as institutions relevant for innovation success [5,24] and has also included entire production and consumption systems [25] which must be reorganized to yield more sustainable economic structures [26]. Research on national innovation systems (NISs) highlights that innovation patterns differ systematically across countries due to macro level differences in institutions, policies, and practices to promote industrial and scientific innovations and also includes micro phenomena that shape innovation [27-32]. Subsets of NISs include regional innovation systems, sectoral innovation systems, technological innovation systems [31] and industrial innovation systems [14]. More recently, attention has been focused on how to transition from a historically predominant sociotechnical regime to a new socio-technical regime by nurturing and developing niches which allow the new socio-technical regime to mature $[33,34]$. The niche is a critical concept due to its role in the emergence of 
novel technologies; niches are protected spaces, i.e., specific markets or application domains in which radical innovations can develop without being selected out by the pressures of the prevailing regime [33]. The transition can be deliberate and intended and achieved through a broad range of actors. Thus analytical interest has shifted from technological innovation contributing to economic growth of countries to new technologies as nuclei for enabling socio-technical transitions [33].

Additionally, the industrial ecosystems literature [14,35], which applies concepts from natural ecosystems [14,36], emphasizes technology and suggests that wastes and effluents from one process serve as the input material for processes as in natural ecological systems [37]. An industrial ecosystem can develop with intentional, strategic and institutional pursuit of environmental goals [38,39]. Just as species diversity contributes to maintaining resilience in biological ecosystems, analogously in industrial ecosystems the presence of various types of organizations promotes resilience by enhancing the ability to recover from shocks, as each type performs different functions and provides different services in the ecosystem and their interactions promote resource flows in increasingly complex networks as the system matures [36]. Resilience refers to the ability of the system to retain essentially the same function, structure, identity and feedbacks, indicating that the system stays in the same "basin of attraction" [35]. Thus, along with industrial symbiosis and inter-firm resource sharing [18], it should be noted that better management of interfirm exchanges can help to maintain industrial ecosystem resilience [35]. By increasing business competitiveness, reducing waste and pollution, creating jobs and improving working conditions, such industrial ecosystems can stimulate regional development [40]. In this vein, Koh et al. [41] propose a circular framework for supply chain resource sustainability (SCRS) that takes into account the triple bottom line [42]. Koh et al. [41] view SCRS in terms of streams of resources including carbon and other emission related resources, energy resources, material, and social resources. They suggest various strategies for ensuring sustainability including life-cycle mapping and utilization of resources, capture and quantification of environmental, economic and social capital, and identification and management of interconnectedness and overlaps in resources cycles.

Although researchers $[4,16]$ have argued for the need to go beyond sustainability and create sustainable wealth by moving towards circular value ecosystems and using technology and innovation to transform residues into valuable resources to reduce environmental impact, research on this topic is still nascent. Additionally, further research is required to understand and overcome the challenges of transitioning from the conventional paradigm of economic growth to a system that fully incorporates the impact of activities on the environment. 


\section{Entrepreneurship and social entrepreneurship}

It is well known that the proper allocation of resources to entrepreneurship which brings new ideas and combinations is critical for innovation, competitiveness and economic development [43-46]. In the absence of appropriate incentives, entrepreneurial activity by individuals may not be forthcoming. Indeed, entrepreneurship is required for commercializing inventions as invention alone is insufficient. Even in industrialized economies, it is acknowledged that it is necessary to facilitate the establishment of entrepreneurial firms. Hence, institutional support is necessary for promoting entrepreneurship. Entrepreneurship may be public or private. Klein et al. [47] note that productive public entrepreneurship includes alteration to the rules of the game, creation of new public organizations, innovative management of public resources and spillovers from private actors to the public domain. Additionally, privately undertaken entrepreneurship in pursuit of private interests may have beneficial spillover effects on the public domain. Thus, a public entrepreneur may be either a private or a public actor. Baumol et al. [48] suggest that a combination of big firm capitalism and entrepreneurial capitalism is the most beneficial for economic performance. A substantial body of research on entrepreneurship increasingly recognizes that venture creation and small business development are ways to improve economic growth via the creation of new product markets, jobs and wealth $[49,50]$.

However, the primary beneficiaries of globalization are globally competitive and digitally connected firms and industries with requisite skills to participate in the global economy. Additionally, high levels of inequality within nations can effectively create mobility barriers for individuals who are unable to participate in the market economy for a variety of reasons including lack of capabilities, access to resources, social capital and networks [51]. Hence, a key concern of developing country governments is to promote new services aimed at involving the bottom of the pyramid (including women and the disabled) to improve well-being as well as economic activity [10,52]. Most developing economy governments view supporting entrepreneurship and innovation as critical to enhancing competitiveness. Additionally, social entrepreneurship, a type of entrepreneurship that focuses on solving socio-economic problems at the bottom of the pyramid [53] is an important mechanism for linking bottom of the pyramid populations with more advanced sectors of the economy. Such linkages enable the flow of resources, ideas, capital and talent to facilitate the development of new markets [5].

\section{Inclusive growth}

Inequality has been rising in both advanced and developing economies, inter-alia, due to globalization and technological change. Inclusive growth refers to both the pace and distribution of economic growth and can be 
accounted for by capturing both changes in growth and income distribution [54]. Past research has argued that high inequality dampens growth through various mechanisms, including by decreasing the purchasing power of a large part of the population, demotivating the average worker leading to decreased performance and commitment, and due to diminished access to health and education [54]. Income inequality was found to impede economic growth in OECD member countries [55]. In contrast to research suggesting a trade-off between economic and income inequality [56], new perspectives [57] suggest that ensuring equality is critical for sustainable growth [54] and that redistribution is not inherently detrimental for growth [58].

Aoyagi and Ganelli [54] note that although poverty reduction in Asia over the past two decades has happened faster than anywhere else in the world, the bulk of the population still lives in countries with rising inequality. They also find that the effect of expanding fiscal redistribution on inclusive growth could lead to an estimated improvement in inclusive growth ranging from $1 \%$ to about $8 \%$ points.

Sen examines episodes of growth in developing countries and argues that inclusive growth is influenced by institutions (such as the rule of law, changes in corruption, democratic accountability) in different economic growth regimes classified as four types [59]: (1) a regime of "miracle growth" (average increase in per capita of 5\% per annum or more); (2) one of "stable growth" where average increase in per capita income is between $0 \%$ and $5 \%$ per annum; (3) a regime with "stagnant growth" where average increase in per capita income is around 0\% per annum; (4) a growth regime which is called "growth crisis" where the average change in per capita income is negative [59]. His analysis of 24 developing countries reveals that inclusive growth is more likely to be observed when economic growth has accelerated and the country is in growth maintenance phase and when inclusive institutions have emerged [59].

Thorat and Dubey's study of inclusive growth in India during the period 1993-94-2009-10 finds that rural poverty declined during 1993-2010 by $2.5 \%$ annually with a major acceleration in the second period, from $2.2 \%$ during 1993-2005 to 4.4\% during 2005-2010, the second period being more poverty reducing [60]. However, during 2005-10 some segments of the population benefited more than others (for example, the higher castes, Muslims, other religious minorities and the scheduled tribes) whereas for the scheduled castes poverty declined at lower rates. They conclude that broad-based pro-poor policies need to be supplemented with policies for specific groups to ensure inclusive growth.

The literature on Bottom of the Pyramid markets (BOP) and pro-poor innovation [10] supports the idea that equality is not detrimental to growth at the micro level. BOP markets consist of over four billion people who live on less than $\$ 2 /$ day and represent multiple cultures, ethnicity, literacy, capabilities and needs and can be segmented in various ways. Prahalad argues that converting these fragmented markets to an 
organized private sector market (worth about $\$ 5$ trillion in purchasing power parity) is an important challenge and opportunity to create new markets [10]. These markets exist in rural and urban settings and access to the market is a major problem in places like India and Brazil. Commitment to building awareness of products and services, ensuring affordability, access, and availability are critical for innovation at the bottom of the pyramid. Products and services must be designed for local markets with deep immersion into consumers' lives to obtain insights [10]. Additionally, to scale innovations, global standards must be met. Solutions are likely to be specific to different locations and industries and new ecosystems specific to markets can be created to economize on capital requirements. Profitability depends on large volume, low capital intensity, low margin per unit and high return on capital employed. Consequently, business model innovation is critical [10].

\section{Sustainability in renewable energy ecosystems}

A major benefit of renewable energy is the reduction of greenhouse gas emissions, environmental impact and use of fossil fuels [61]. Although renewable resources are often seen as sustainable resources, this is not always the case as renewable refers to the energy resource and not to the processes associated with the extraction and refining of the resource [61]. In many instances, extracting energy from a renewable resource still requires fossil input which will have an impact on the environment and, therefore, on sustainability. Other factors that influence the environmental sustainability of a renewable resource include materials and production processes used and the energy system in which it is integrated. While sustainability is a complex concept and measures include economic and social indicators, Pierie et al. note that measures should include the efficiency, carbon footprint and environmental impacts of renewable resources to enable better planning and decisionmaking towards achieving a more sustainable energy system [61].

Terrapon-Pfaff et al. note that small-scale and community-based renewable energy projects are important forms of development assistance for reaching the energy poor in developing countries [62]. They examine 23 local development projects supporting renewable energy technologies including solar, wind, hydro and biomass power used for food preparation, lighting, electrification or irrigation in over 17 different developing countries in Sub-Saharan Africa, Latin America, Asia and the Middle East. They found that access to sustainable and affordable energy services is crucial for reducing poverty in developing countries and smallscale projects did improve access to energy. Even though only five interview partners were able to quantify the increase, these five projects alone provided 350 additional persons with clean electricity, lighting, heating or cooking solutions with up to 2500 additional people gaining access through on-going scaling activities. Moreover, renewable energy use reduced deforestation through reduced use of firewood, preserved 
diversity, prevented unsustainable land-use changes and reduced smoke and GHG emissions by replacing wood and fossil fuels as the energy source. Most of the technological devices introduced in the project were still operating suggesting that the projects were successful in reducing $\mathrm{CO}_{2}$ emissions and fire wood and fossil fuel use on an ongoing basis. Overall, the majority (78\%) of projects continued to operate and were in use by beneficiaries, $48 \%$ were fully functioning and 30\% were largely operational, while $13 \%$ were operating to a limited extent and $9 \%$ failed. Key factors for success were the effective functioning of the technical system, financial viability of the service, effective management of the project and external factors such as institutional and policy developments or environmental conditions [62].

Other papers on renewable energy and sustainability focus on experiments to optimize or model individual renewable energy technologies for specific purposes [63,64]. However, insufficient efforts have been made to understand how ecosystems for renewable energy in developing economies can facilitate socio-economic sustainability despite the overwhelming need for energy and importance of establishing industrial ecosystems to ensure sustainable socio-economic development.

\section{A framework for creating niche ecosystems for the bottom of the pyramid}

This section outlines a framework for catalyzing transformation at the base of the pyramid for sustainable and inclusive growth. The framework encompasses both the macro and micro levels. Thus, both policy changes by the government at the national level as well as by organizations at the micro level to support innovation, collaboration and entrepreneurship are considered. The framework is developed from research and insights from cases and can increase understanding of how ecosystems for renewable energy facilitate sustainable and inclusive growth in developing countries.

As noted earlier, industrial ecosystems, a subset of NISs, are analogous to natural ecosystems. Establishing an industrial ecosystem in a new sector such as renewable energy in regions of a developing economy where such technology was not widespread (for example, for BOP populations) involves innovation as it is new to the region or country even if it is not new to the world [30]. As noted in the previous section, transitioning to a new socio-technical regime from a previously dominant one necessitates both social and technological change. It also requires reorganizing structures or establishing new ones to enable new industrial ecosystems (such as an ecosystem for renewable energy) to mature. Also, institutions as well as governments, non-governmental organizations (NGOs), and research institutes are among the range of actors necessary for innovation success [24]. Additionally, a function of NISs is to create markets [32]. Research on sustainability transitions emphasizes that technological and other innovation is increasingly viewed as a way to catalyze socio-technical change [33]. The lack of products and services targeted at base of the pyramid populations presents an opportunity to 
establish new niche markets and to scale them eventually to address needs in other, similar, global markets. In summary, past research suggests that new technologies can catalyze change and usher in major restructuring.

Research also notes the importance of promoting entrepreneurship to enable the adoption and diffusion of innovations [5]. Entrepreneurship diffusion at the base of the pyramid allows greater participation of the target population in rural and semi-urban areas where cash and the means to earn it are in short supply. Thus, facilitating the emergence of entrepreneurship, especially entrepreneurship focused at the bottom of the pyramid (BOP) is critical to enable the emergence of new niches.

At the macro level, government policies can address the challenge of promoting innovation for the bottom of the pyramid. These include an explicit policy focus on inclusion and sustainability through various missions and different agencies. New policies targeted at BOP populations can alter the trajectory of the innovation system over time. Additionally, public academic institutions can help to obtain first-hand knowledge of the needs of the target population and ensure that they are being addressed. For example, academia can focus on demonstration projects for new technologies.

As noted earlier, ecosystem resilience, which refers to the ability of the ecosystem to respond to a disturbance and recover rapidly, requires the presence of many different types of organizations and interactions and exchange across these organizations. Over time, interactions across different types of organizations enhance the ecosystem's stability and its ability to respond to change. Hence, efforts must be made to facilitate interactions across the ecosystem both at the macro and micro levels. Thus, interactions across government, academia, non-governmental organizations and various entrepreneurial organizations must be nurtured to promote innovation, facilitate the flow of knowledge and skills, and ensure the growth of a sustainable ecosystem for renewable energy at the bottom of the pyramid. To promote entrepreneurship, national agencies can sponsor innovation projects and provide grants to reduce the risk of investing in technologies for BOP populations. Special benefits to entrepreneurs and small business owners can facilitate entrepreneurship. Such efforts will foster the emergence and diffusion of entrepreneurship. At the micro level, entrepreneurs must focus on building awareness, and making their products and services affordable, accessible and available when addressing BOP markets [10]. Moreover, environmental sustainability can be built into the system to ensure that products and services are sustainable, particularly as reducing waste and re-using waste outputs as inputs over the life cycle can help to reduce cost [61].

Finally, to reach the target population, it is critical to develop low-cost business models as affordability is of utmost importance for BOP markets. Often new infrastructure must be built to reach the target population, so relationships with new constituencies must be created. For example, many 
low cost innovations in the new digital economy include users as part of the process, as for example, in the hospitality industry [65], or include sharing resources (e.g., Uber, Lyft, AirBnb). Thus, strategies such as sharing resources, reducing waste and reusing outputs as inputs for new products and services, can be used to develop frugal innovations that provide value to BOP populations. Scaling these will require embedding quality standards and processes in organizations to ensure reliability and continuous availability of the product/service.

The following three propositions are derived from the theoretical background above:

1. Fostering collaboration and innovation across the ecosystem is necessary to promote adaptation.

2. Nurturing entrepreneurship and social entrepreneurship is necessary to promote participation and exchange and enable emergence of new niche markets (such as renewable energy for BOP populations).

3. Developing low cost business model innovation is necessary to facilitate niche creation.

Together, they help in the development of the ecosystem and enhance its resilience and stability. Figure 2 below provides a representation of the framework.

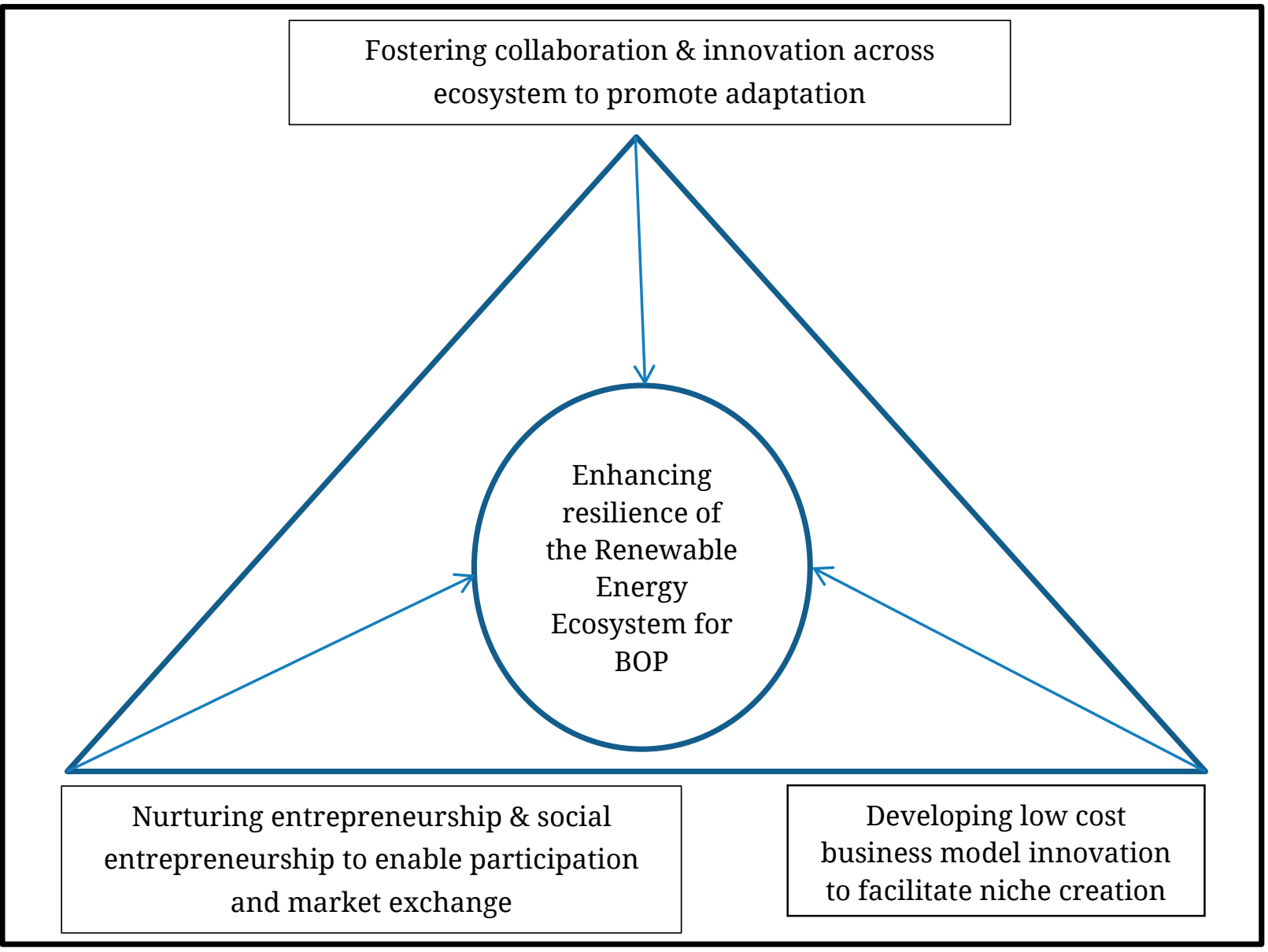

Figure 2. A framework: Three pillars for creating ecosystems for the bottom of the pyramid. 


\section{METHODS}

Case study methodology is used to examine the research question: How can ecosystems for renewable energy catering to BOP populations promote environmental and socio-economic sustainability? Case study methodology is useful and appropriate when asking how or why questions and when the phenomenon is rare, unique or critical for theory creation [19]. New theory is developed by extending existing theory [66] by linking the literatures on sustainability with industrial ecosystems and renewable energy. Inductive case analysis is used to provide rich context and helps to understand how a renewable energy ecosystem can be designed for sustainability. Finally, the methodology helps to make concepts and processes concrete [67].

The case findings reported in this paper were drawn from interviews conducted as part of the author's Fulbright research study on the commercialization and adoption of renewable energy by base of the pyramid consumers (2013-2014) and follow-up studies thereafter. About 40 semi-structured interviews were conducted in public and private sector organizations during the summers of 2013-2014. Interview questions ranged from questions about the background of the interviewee and the organization and history of involvement with renewable energy, the technology, university-industry and other collaborations and additional mechanisms used to commercialize the technology to make it available to the BOP population. Additional questions focused on the organizational structure, capabilities mastered, and challenges facing the organization. General questions regarding the state of capabilities and R\&D/innovation in renewable energy in India, and challenges associated with taking innovation and commercialization to the next step were also included.

Interviewees included government officials, scientists, university researchers, CEOs and senior executives of companies, senior officers of non-governmental organizations (NGOs) serving Bottom of the Pyramid (BOP) consumers in the renewable energy sector as well as users of renewable energy technologies [19]. Approximately 10 percent of the interviewees were female. These data were supplemented by site visits, presentations, annual reports, other historical and recent published material and material obtained from conferences on renewable energy.

The Indian context is an appropriate setting to study renewable energy industrial ecosystem creation in rural India for sustainability. New policies on renewables were enacted with a focus on new energy technologies to alleviate poverty and facilitate social inclusion of the rural poor, a central element in renewable energy programs. These included the Jawaharlal Nehru National Solar Mission (2010) focused on accelerating the adoption and diffusion of solar energy and which facilitated the development of one of the largest generation based markets in the world [68]. Additionally, the government also focused on off-grid solar energy projects and introduced various schemes to provide electricity and other energy services to rural areas lacking these services. Similarly, the 
National Policy on Biofuels (2009) aimed at biofuel production in India, focused on using non-food feed-stocks raised on degraded land for biofuel production. The government also made use of rural employment schemes to facilitate feedstock production and processing for the nascent biofuels sector [5].

Interviews were transcribed and the data were analyzed by using categorization and pattern-matching techniques [19,69,70]. First the literature on sustainability, industrial ecosystems, entrepreneurship and inclusive growth and renewable energy was studied. Propositions were developed by iterating from theory to data and vice versa and pattern matching was used in conjunction with theories noted above [19]. These analyses and propositions yielded a conceptual model of ecosystem creation for renewable energy at the bottom of the pyramid that takes into account environmental and socio-economic sustainability. The results from case studies are presented in the next section.

\section{RESULTS}

The framework presented earlier is applied to provide insights on the creation of niche ecosystems for innovative, renewable energy-based sustainable products and services in India. Findings are analysed in light of the three propositions outlined in the framework and presented accordingly.

\section{Fostering Collaboration and Innovation across the Ecosystem}

At the macro level, various policies and missions were enacted by the government of India to establish the renewable energy ecosystem by fostering innovation and collaboration. Social inclusion was emphasized in the 12th Five Year Plan (2012-2017). NITI Aayog (National Institution for Transforming India) which replaced the Planning Commission, continued the focus on eliminating poverty and addressing the United Nation's Sustainable Development Goals (SDGs). In addition, various programs such as the Mahatma Gandhi National Rural Employment Guarantee Act (MGNREGA) and Sarva Shiksha Abhiyan (SSA) address poverty alleviation [71].

In addition to increasing the effectiveness of anti-poverty programs, facilitating sustained rapid growth that is employment intensive is necessary for government revenues to grow, which, in turn, enables the expansion of social expenditures (Government of India, 2018). Hence, besides policies and missions such as the National Solar Mission (2010), National Wind Solar Hybrid Policy and National Policy on Biofuels, the Government of India, established various institutions (through the Ministry of New and Renewable Energy (MNRE)) to support research, development and commercialization of renewable energy technologies and the creation of ecosystems for renewable energy in India. These include the National Institute for Solar Energy, National Institute for Wind Energy and Sardar Swaran Singh National Institute of Bio-Energy as well 
as the Indian Renewable Energy Development Agency (IREDA), a nonbanking financial institution, which provides loans for renewable energy projects.

Further, the Department of Science and Technology (DST) also worked with leading technical institutions to develop and disseminate innovative technologies. Researchers at technical institutions were funded to conduct demonstration projects to design products and services to suit the needs of the target population, test technologies and develop standards. For example, researchers at IIT-Delhi worked on converting manure into biogas and designed cook-stoves using biogas as fuel and helped demonstrate their use in the field; both technologies were relevant for rural populations. Additionally, DST promotes international collaboration in research under the Clean Energy Research Initiative through Mission Innovation (MI), a global initiative between 22 countries and the European Union, to accelerate clean energy innovation and facilitate off-grid access to electricity [72]. Thus, knowledge from external sources is made available locally.

Additionally, schemes such as the Technological Advancement for Rural Areas (TARA) scheme promote innovation for BOP populations through DST's Science and Technology (S\&T) Programme for SocioEconomic Development. TARA aims to develop S\&T packages for rural and remote areas. Core Support Groups (CSGs) identify location-specific problems, convert them into S\&T research challenges, and develop and demonstrate S\&T packages for transfer. DST supported 22 CSGs in 14 states during 2017-2018. Achievements include cost effective solar space and water heaters developed by the Himalayan Research Group in Shimla. The devices reduced female drudgery by halving the number of trips for fuelwood collection/annum and saving about $40 \%$ of fuelwood, mitigating 2.5 tons of $\mathrm{CO}_{2}$ emission/annum/panel. The technology was demonstrated successfully in Himachal Pradesh and extended to the cold desert area in Zanskar Valley in the Ladakh region of Jammu and Kashmir [72].

NB Institute of Rural Technology (NBIRT), a CGS working in the state of West Tripura made innovative S\&T interventions for lighting using a photo voltaic (PV) integrated Micro Solar Dome to provide lighting where conventional power was not available or unreliable. The integrated PV module charges a battery during daytime and provides light at night for about 4 hours. NBIRT also developed a solar power operated micro pump and water purification system to provide water for drinking and sanitation. Similarly, a CSG in Hyderabad developed an improved Solar Cabinet Dryer integrating solar energy to dry and process locally grown and easily available ingredients. These programs deploy expert teams to focus on challenges faced with regard to energy access in specific areas and develop solutions thus facilitating innovation and the creation of the niche ecosystem through interactions across government, research organizations and the local rural population [72]. 
In addition, DST also supports development of new science and technology (S\&T) solutions by young S\&T professionals via its Scheme for Young Scientists and Technologists in the areas of agriculture, health and nutrition for the non-farm sector. In 2017-2018 around 45 projects were recommended for support. Likewise, S\&T interventions through the Uttarakhand State Council of Science and Technology targeted natural resources, skills and traditional crafts to generate livelihoods in 60 villages in the state of Uttarakhand. Capacity-building is addressed by strengthening local institutions in project sites and by disseminating new skills. Program interventions led to livelihood diversification in many areas (DST 2018). Thus, government programs and schemes were successful in fostering innovation and nurturing interactions across many organizations such as academic and technical institutions, support groups and local organizations to provide needed solutions [72].

Policies enacted and institutions established by the Government of India to support renewable energy are critical for building the infrastructure for renewable energy. Additionally, DST's focus on innovation aimed at BOP populations, support for new technologies through schemes to fund demonstration projects, and for entrepreneurship and local capacity building to enhance livelihoods emphasized the importance of this ecosystem. It also signalled the availability of new opportunities in an upcoming industry to entrepreneurs and established organizations. These initiatives involved collaborating with local institutions, universities, technical institutes and core support groups to reach the targeted communities. As a result, linkages were established with various organizations that gave DST and other associated organizations first-hand understanding of conditions faced by BOP populations and of their needs. These linkages also helped to enable flows of communication and knowledge exchange from the centre to the periphery and vice versa. Even though these initiatives were top down to begin with, implementation of the policies through schemes such as the TARA scheme and CSG projects led to greater outreach with other organizations and dispersion of knowledge through training and capacity building. The strengthening of these linkages contributed to enhancing ecosystem stability and resilience.

At the micro level, start-up organizations such as BlueSky Power, also provided innovative solutions and grew by fostering collaboration. The company was founded in 2008 by a software engineer who returned to India after having obtained a business degree, work experience in the software industry and founding a successful start-up in USA that was eventually sold to a company in Silicon Valley. The founder-entrepreneur was interested in a socially-conscious business and, after spending a year understanding the policy regime in India, decided to enter the Indian solar industry. He persisted with the project despite facing early policy challenges such as the regulation that required ownership of at least 50\% of the land needed for a solar project. Subsequently, the policy was 
changed and companies were given 180 days to obtain land after winning a project. BlueSky Power built its first grid connected solar power plant in Punjab in 2009, north of Amritsar. Interest in solar energy grew, and the Jawaharlal Nehru National Solar Mission also provided a boost to the solar energy industry.

BlueSky Power (the name of the company has been disguised for confidentiality) engaged in interactions with a various types of organizations. From the beginning, the company interacted with the government by providing inputs to build policies for solar energy. Taking advantage of the policy changes, BlueSky Power developed various projects throughout India in various states and was operating in nine states by 2014. The company signed contracts and worked with various distribution companies that bought power from it to sell to consumers. The cost of energy for the first project was Rs. 17 per unit (Rs. $17=$ USD 0.24 as of 11/4/2019), and dropped to Rs. 6.5 or Rs. 7 per unit (Rs. 6.5-7 = USD 0.920.099 as of $11 / 4 / 2019$ ) over a period of five years. Over time, as the renewable energy ecosystem grew, in addition to contracting with the government, the company branched out to work with the private sector. As the company expanded its operations, its interactions included reaching out to leading international research institutes such as Fraunhofer-Gesellschaft in Germany for technical expertise in specific knowledge domains. Interactions with the government, research institutes and others helped to increase BlueSky Power's ability to access knowledge, build resources and capabilities, thus contributing to the stability of the ecosystem.

Likewise, organizations like Mini Wind, Solar Lighting India, Village University and Flora Green (as noted below; names of these organizations have been disguised for confidentiality) took advantage of linkages with the government, academic institutions and funding agencies in India and internationally, along with partnerships with local entrepreneurs, banks and non-governmental organizations serving BOP populations in rural areas to help build the renewable energy ecosystem. In the case of Mini Wind, small windmills were an innovative product that could generate energy at low wind speeds and at low cost; collaborating with the Centre for Wind Energy allowed the organization to provide training on a larger scale, while collaborating with villagers enabled the villagers to acquire skills and maintain the system in the villages. Similarly, Solar Lighting India used collaborations with international agencies and an innovative financial model to provide financing for the rural poor. Village University took advantage of collaborations with the government, foundations and corporations to provide training in solar energy technologies to older village women who would return to their villages with this knowledge. Flora Green created a pathway to recycle waste flowers from temples into fertilizers and incense by connecting with temple committees, botanists, farmers, flower traders and fertilizer manufacturers. In each of these cases, collaborations enhanced the resources and knowledge available to 
these organizations, built the capabilities of the target population, created a channel to the target market and, thereby, helped to stabilize the ecosystem and enhance resilience.

\section{Nurturing Entrepreneurship and Social Entrepreneurship}

The Government of India's Department of Science and Technology (DST) supports entrepreneurship. Technology Business Incubators (TBIs) were established in and around academic, technical and management institutions to tap technologies for venture creation using existing infrastructure and expertise. More than 120 TBIs and Science and Technology Entrepreneur Parks (STEP) had developed competence to become state-of-the-art incubators. New TBIs were established at Pune, Bangalore, Lucknow, Hyderabad, Bhopal, Jammu, Surat among other locations [72].

Various start-ups at TBIs had developed innovative products. For example, AirOK Technologies, a company incubated by IIT Madras, developed the Air OK Smart Purifier to remove environmental pollutants like particulates in hospitals, industry and waste management facilities. Similarly, a Smart Farming Collective was incubated by an alumnus at IIT Madras, the founder of Aibono. The company focuses on providing precision farming input and end-to-end management advice for fruit and vegetable farmers using sensors, cloud applications, data analytics, social and ambient sensors, and drone imaging to assess crop stress [72].

DST also established a national award for Technology Business Incubators and provides early-stage seed funding to start-ups to facilitate entrepreneurial entry. In 2017-2018, 11 TBIs were recommended for seed funding support. TBIs also initiated programs to accelerate innovation through mentoring and investment preparedness. Centres of Excellence were also established to provide expertise and help establish linkages with national and international partners. The NIDHI PRAYAS program, a preincubation grant initiative, addresses the gap in funding in taking an idea to the prototype stage, and supports about 100 innovators. Finally, an Entrepreneurs-in-Residence programme provides entrepreneurs a fellowship of up to Rs. 30,000 (USD 423.19) for one year to minimize the risk of pursuing entrepreneurship. Entrepreneurship and innovation are also encouraged through the New Generation Innovation and Entrepreneurship Development Centre and the India Innovation Growth Program, a public-private partnership between DST, Lockheed-Martin Corporation and Tata Trusts (DST, 2018). Women's entrepreneurship is supported via an accelerator program and mentorship [72]. Overall, at the macro level, support for entrepreneurship and social entrepreneurship (entrepreneurship focused on underserved populations) has facilitated the creation of new markets and niches including at the bottom of the pyramid as suggested by the framework.

Examples of entrepreneurship at the micro level include Mini Wind (the name of the company has been disguised for confidentiality), a wind 
energy company founded in 2010 to cater to the underserved in rural areas in India by an engineer with expertise in wind energy from the US and Ecuador. The company meets the power needs in villages by training, supplying and supporting rural mechanics to build, install and maintain low-cost wind turbines. Mini Wind produces turbines designed to operate efficiently at lower wind-speeds common in most regions. Over time, the company has grown to help villagers use wind energy for various applications such as water pumping, oil and millet processing and digital carpentry. The company has formed partnerships with villagers, rural entrepreneurs, as well as partnerships for manufacturing components such as turbine blades, installation of towers and for training. Villagers generate livelihoods as entrepreneurs, and support the ecosystem. In addition, though the organization is focused on small wind energy systems, in some cases, the systems have been combined with solar systems to alleviate problems of intermittency with both wind and solar energy. Over time, the organization developed an open source 3D printer to serve as a manufacturing hub for rural development. The printer will initially use recycled plastic for printing components and will graduate to testing composites (plastic and natural fibres) and ceramic components. This innovation was developed in collaboration with partners. Additionally, the organization has created teaching centres at the National Institute for Wind Energy and other locations in India and other countries.

Similarly, Solar Lighting India (the name of the company has been disguised for confidentiality), another enterprise serving the rural poor, provided solar lighting systems for BOP customers in villages that lack or have limited access to the grid. Realizing that, despite their willingness to pay for products, obtaining financing is hard for the poor because they have no credit history, the founder CEO built small-scale solar lighting systems. He also worked with rural banks to create affordable "lease-toown” schemes to make capital-intensive PV systems affordable, thereby facilitating financial inclusion of the rural poor.

A third organization, Village University (the name of the organization has been disguised for confidentiality), an educational non-governmental organization, was established in 1972 to address poverty and the energy crisis in India, and trains older village women across India as solar engineers. They learn how to install integrated circuit boards for solar home lights and to assemble solar lanterns and compact fluorescent lamps, parabolic solar cookers and solar water heaters to help electrify their villages. Upon returning to their villages, they are able to generate livelihoods for themselves as local entrepreneurs by providing various services, including maintenance. Over four decades, the program has extended to 70 countries (including those in Africa and Latin America) and has provided solar power and lighting to 550,000 people in 1300 villages worldwide. The training program is funded by the government of India, corporate partners around the world and through grants from organizations such as United Nations, the Skoll Foundation in the United 
States, the Fondation Ensemble in France and the Het Groene Woudt in the Netherlands.

A fourth start-up, Flora Green (the name of the company has been disguised for confidentiality), collects flower waste from temples and mosques for processing into natural products such as soap, incense, biofertilizer and bio-degradable Styrofoam to reduce pollution and pesticide discharge. The company has pioneered flower-cycling to process waste flowers and applied for five patents. The organization has employed more than 200 women who previously worked as scavengers in the informal sector to process flower waste, giving them an opportunity to improve their earnings from Rs 10 to Rs. 200 per day.

Overall, these entrepreneurial start-ups provided training, created innovative products and services that enabled livelihood generation for BOP populations, a segment hitherto ignored by established organizations. By addressing the needs of this population these start-up organizations facilitated participation and social inclusion, thereby helping to build a new market for renewable energy. Contrary to the view that markets exist a priori, the cases discussed in this paper suggest that entrepreneurship and entrepreneurial ventures are needed to create new markets. In recognition of the importance of entrepreneurship in the diffusing new technologies and innovations for BOP populations, the Government of India has also incorporated support for entrepreneurship as part of its mandate. This emphasis on entrepreneurship and attempt to distribute the task of diffusing technological solutions to entrepreneurial ventures contrasts with the historical stance of the government of India to conduct implementation via centralized departments and public sector organizations. At the micro level, the emergence of village entrepreneurs is interesting as it highlights the understanding that BOP populations need to develop and nurture entrepreneurial capabilities to ensure that this market is served.

\section{Developing Low-Cost Business Model Innovation}

Catering to the rural population and other BOP segments requires developing low-cost business models. As BOP consumers are extremely cost-sensitive, innovations must be frugal. Moreover, making the product/service accessible is a challenge as channels for after-sales service and maintenance are often lacking. In many cases large multinationals have not provided sufficient service and maintenance to meet the requirements of this population. Thus, both business-model innovation and product/service innovation are required to meet their needs.

In the case of Mini Wind, the founder and his team created small, low cost turbines that were suitable for use in villages. The typical turbine system consists of a turbine, a tower to raise it above trees and other obstacles, and a battery bank to store power and electronics. The product uses an open-source design adapted to render it suitable for rural conditions in India. To keep costs low, the company mobilizes pro-bono 
engineering talent provided by volunteers who have engineering expertise in 3-D modelling, structural analysis, aerodynamics or fluid dynamics and power electronics. To ensure that service and maintenance needs were met in villages, the company trained village mechanics and entrepreneurs to become certified Village Partners who could design, install and maintain wind systems and serve others in the villages. Village Partners could also become certified regional trainers. The model also included certifying selected entrepreneurs to manufacture components and assemble turbines. Training sessions held in research centers like the National Institute for Wind Energy allowed the organization to scale and grow. Additionally the attempt to use 3D printing to create a rural hub for manufacturing indicates the creation of a new market to address the needs of the rural poor and facilitate socio-economic development.

Mini Wind's turbines are expected to cost Village Mechanics about Rs. 23,000 (350 USD) to build a 350 Watt machine. With economies of scale, these costs could be lowered to reduce the sale price of the turbine enabling small wind to be roughly equivalent to current solar PV costs (about $1 \mathrm{USD} /$ watt). The smallest turbine at 100W has a manufacturing cost of Rs. 8000 (USD 112.9), while the largest turbine is $2.5 \mathrm{KW}$ with a sale price of Rs. 130,000 (USD 1834.8). Even in Northern Tamil Nadu which has poor wind and lots of sun, Mini Wind's turbines are competitive to solar photovoltaic (PV) panels. In many cases PV and wind are complementary as some seasons are windy and others sunny. Besides diffusing renewable wind energy, the business model developed by Mini Wind helped to diffuse entrepreneurship and skills.

In the case of Solar Lighting India in southern India, the founderentrepreneur developed financing for the rural poor to enable them to have access to solar lighting. Partnerships with Tata BP, SWEA Bank, IFC and others facilitated the company's growth and by 2014, the company was serving over 180,000 households. Rural customers noted that besides significant savings in energy costs, using Solar Lighting's products also benefited their children's education. As banks were reluctant to finance BOP customers without collateral or credit history, Solar Lighting, together with its NGO partner, provided a loan guaranty on behalf of borrowers, thus enabling them to obtain financing. As a result of these loans, rural customers were included in the financial system leading the CEO to claim that solar energy should be regarded as an engine of development.

Additionally, the CEO of Solar Lighting noted that, just like consumers in urban markets, the rural poor also deserve servicing and maintenance for systems they purchase. Therefore, energy service centers are an important part of the organizational structure. The company also added sales of fuel-efficient cook stoves (using biomass as fuel and charcoal briquettes) to its product portfolio to leverage its distribution network. In 2014, the company had 36 offices, 278 employees and been profitable for the past 10 years. Moreover, the CEO emphasized that besides solar energy technologies, customers needed complementary innovations. For 
example, the sewing machine used by a poor tailor needed to be reinvented to meet the needs of this population because the current machine assumed the existence of power supply from the grid. However, power supply from the grid is often limited or non-existent. In such ways, lack of innovation for BOP populations creates inefficiencies that can be mitigated by distributed energy systems. He also noted that it was critical to develop management from the bottom-up, and had trained and developed people who could reach the rural poor even if they were not highly educated.

Blue Sky Power also adopted new business models for private sector projects. For example, rooftop projects were undertaken for various companies to generate solar power to be fed to the grid. This included a pan-India project with a major Indian real estate company. Working with large companies instead of individual consumers was important to ensure that the project would be of sufficient size and scale. Smaller projects were not viable because of the challenges of financing risk, construction risk, and risk of non-payment. Additionally, there was the risk of resistance from distribution companies that were already supplying power. However, many of the larger solar projects were set up in rural areas to promote inclusive growth and provide employment in construction and infrastructure development while generating power for these areas, most of which did not have power even if they were connected to the grid. Here, delivery, maintenance and application models were different but the same basic technology was deployed as in small-scale projects. Taken together these helped to build the socio-economic sustainability of the solar energy ecosystem while reducing environmental impact.

While Village University focuses on electrification of villages through renewable energy by older women, a key goal is to help them generate livelihoods and become self-sufficient. The organization selects trainees from remote villages and sends them back to electrify their village. The program aims to make populations autonomous by providing know-how. The model emphasizes the following principles: reliance on local skills and indigenous solutions developed by combining traditional skills and experiential learning rather than importing skills from elsewhere; use of sophisticated technologies with an emphasis on having them in the hands of the communities so that they are not exploited; and respect for the equality and outstanding capabilities of women. Funding for the training was provided by the Government of India, foundations and corporations. Solar electrification in villages by women attending this program in villages across India, Ethiopia and Benin, has enabled the lighting up of households, schools and streets, safe delivery of babies in solar-lit homes, refrigeration of immunization products using solar electrified equipment, and transformed villages. A solar engineer from Kashmir trained by Village University returned to her village to work on electrifying 66 households for which each household would pay a small subscription fee when the solar system was set up. Electrification of villages reduced 
firewood and fossil fuel consumption, produced lighting year-round, increased free time available to women and saved money. Training the women increased their self-confidence and power in the community as they were paid a salary as solar engineers. Additional entrepreneurial opportunities were available to the solar engineers after their return to the village.

Flora Green's key goal is to generate livelihoods. The company converts flower waste from temples into incense and other product including biodegradable packaging and bio-leathers. Besides preventing pollution of the Ganges, the organization provides opportunities for women's employment and empowerment. Women who previously worked as janitors instead process flowers into incense sticks and other natural products. Innovations include creating a value chain based on flower waste that employs poor women in urban and semi-urban areas to process the flowers and create high quality organic products. Products are marketed online and via dealers to consumers in urban areas. The business model is an example of a company creating a circular economy in which waste is converted into new products.

The focus on developing a low cost business model in each of these cases enables BOP populations to participate and, in doing so, facilitate niche creation. Over time, as the needs of the population are addressed and participation and exchange increase, the resilience of the ecosystem is likely to improve. Improved opportunities to generate livelihoods increases the use of renewable energy, and, thereby, enhances sustainability. It is interesting to note that providing low cost innovations in a distributed fashion helps to raise the aspirations and self-confidence of BOP populations as they begin to acquire new capabilities and see new opportunities within their reach.

\section{CONCLUSION \& FUTURE RESEARCH}

Additionally, findings from applying the framework to India suggest that creating ecosystems for renewable energy that specifically address the needs of target BOP populations is critical for sustainable and inclusive growth. This involves fostering collaborations and linkages across organizations and the ecosystem, enabling the rise of entrepreneurs that cater to the BOP population and developing innovative low cost business models to reach the target population, thereby establishing niches. In combination, these three pillars help to create new markets at the bottom of the pyramid. At the national level, the government of India has created several initiatives to stimulate BOP innovation. It has partnered with academic and technical institutions across India to increase innovation targeting the needs of BOP populations in rural and remote areas. Goals include increasing access to energy, providing clean water and sanitation as well as providing livelihood generation opportunities and enabling social inclusion. Additionally, the government has encouraged entrepreneurial activity necessary for the diffusion of technological 
innovations by providing stipends, linkages, training, skills and expertise to reduce the risks of entrepreneurship. Finally, several cases of entrepreneurial innovation for BOP populations suggest that renewable energy can boost social inclusion through livelihood generation and even include business models that promote sustainability by upcycling waste into new products. While a beginning has been made in creating an ecosystem for renewable energy for the bottom of the pyramid, continued investment in entrepreneurial start-up organizations is necessary to enable large-scale economic and social inclusion. A conclusion is that ecosystem creation is tantamount to market creation. In many cases, in villages, the institution of the market is non-existent or poorly established. Using an ecosystem perspective, it can be seen from the cases that various types of organizations are necessary to enable exchange to occur and for the renewable energy ecosystem to remain viable.

The paper also highlights that resilience in an industrial ecosystem (such as the ecosystem for renewable energy) is fostered through collaboration across different types of organizations associated with the system and inter-organizational exchanges. Start-up organizations connect with the government and funding agencies to acquire resources and knowledge while at the macro level, government organizations' efforts to stimulate entrepreneurship and innovation for BOP populations by supporting entrepreneurs can help to stabilize such renewable energy ecosystems. Over time, as the ecosystem stabilizes and demand grows, larger organizations may enter the space and offer additional products and services.

Traditional neo-classical approaches to development have assumed perfect information about trade and up-to-date technology produced by the scientific and technological system with national institutions in the background. In contrast, the neo-institutional approach argues that institutions and markets need to be constructed [73]. Insights from this paper suggest that, in the case of ecosystems for renewable energy that serve BOP populations, efforts to encourage rural development need not only be top-down and centralized. In addition, bottom-up, decentralized initiatives by entrepreneurs to address the needs of the target population are critical for the development of local capabilities, entrepreneurship and market creation. Consequently, a two-pronged approach, in which topdown institution-building through national level policy initiatives complements local-level entrepreneurial efforts that facilitate community involvement and participation, is effective in developing the ecosystem for renewable energy. This is possibly because efforts at the village level are critical for disseminating various types of skills, knowledge, entrepreneurial capabilities and for supporting and maintaining demand for new technologies. Although the paper focuses only on one developing economy, India, similar conditions exist in other countries, suggesting it is applicable to other settings. Other developing countries have attempted to create ecosystems for renewable energy to achieve sustainability and 
social inclusion. For example, Itaipu Binacional in Brazil has created an ecosystem for various technologies based on renewable energy to initiate new industries such as solar battery powered automobiles, bio-gas production from waste, and create livelihood generation opportunities for artisanal organizations. Additionally, other mechanisms besides the three propositions outlined in this paper may be helpful in building ecosystems for sustainability and social inclusion. Nevertheless, the micro-finance literature provides support for entrepreneurship at the bottom of the pyramid. Moreover, the political regime and political institutions have not been considered in this paper.

Results indicate that livelihood generation is necessary for participation in any type of market economy. In the case of renewable energy ecosystems established for BOP populations, a focus on entrepreneurship and livelihood generation are necessary to enable BOP populations to participate in socio-economic activity. Findings from this study can be used to increase socio-economic inclusion in other developing countries through entrepreneurial ventures aimed at BOP populations. For example, governments in other developing countries could launch initiatives similar to those launched by the Government of India to stimulate innovation and support entrepreneurial ventures addressing the needs of the target populations so that the risk of entrepreneurial entry is reduced. Moreover, the finding that entrepreneurial ventures must collaborate with various types of organizations to reach the target population and involve the community is critical for the success of similar entrepreneurial ventures in other developing countries. Additionally, training villagers to operate and maintain the wind energy system or solar system and become entrepreneurs in turn is critical for socio-economic inclusion. As a result, villagers are able to participate in the ecosystem and generate improved livelihoods as, for example, in the case of Mini Wind, Solar Lighting India and Village University, thus enhancing socio-economic inclusion. Over time, as village entrepreneurs build demand for these technologies in rural areas and the market grows, other large-scale organizations are likely to find the sector attractive. These lessons can be used to enhance the success of entrepreneurial ventures and, thereby, stimulate entrepreneurship in other developing countries. Similarly, these insights can be used to foster sunrise industries with nascent technologies in industrialized economies as in the case of the biotechnology industry in its early stages in the United States.

Future research could include large surveys to test the framework in other countries. Additionally, future research could examine other mechanisms for stimulating inclusive growth by conducting studies and scenario analyses to investigate differences in ecosystem creation in different contexts and geographies. Studies could also examine how to scale up ecosystems for renewable energy catering to BOP populations and transform them into conventional markets. Additional ways to enhance 
sustainability could also be examined to improve our understanding of how to accelerate ecosystem creation for sustainability.

In conclusion, enabling inclusive growth and sustainability is imperative for developing countries given the large number of people at the bottom-of-the-pyramid currently excluded from the market economy and unable to access the benefits of technology and globalization. Additionally, as energy consumption at the base of the pyramid increases, building sustainability into business models via use of renewable energy or by transforming waste into new products is critical to reduce environmental degradation and reduce the cost of energy. Finally, innovations aimed at the BOP segment would lead to the creation of innovative business models to reach target markets and create new markets that might serve as engines of future growth.

\section{ACKNOWLEDGEMENTS}

I am grateful to the Fulbright Scholar Program for funding a part of my research during the summers of 2013-2014. Also, I would like to acknowledge comments received from colleagues on presentations at conferences of the International Association for the Management of Technology.

\section{REFERENCES}

1. Heal G. Sustainability and its Measurement. NBER Working Paper Series, \# 17008. Cambridge (MA, US): National Bureau of Economic Research; 2011. Available from: http://www.nber.org/papers/w17008. Accessed 2017 Oct 15.

2. Arrow KJ, Dasgupta P, Goulder LH, Mumford KJ, Oleson K. Sustainability and the Measurement of Wealth. NBER Working Paper Series. Working Paper No. 16599. Cambridge (MA, US): National Bureau of Economic Research; 2010. Available from: http://www.nber.org/papers/w16599. Accessed 2017 Oct 15.

3. United Nations. Sustainable Development Knowledge Platform. New York (NY, US): United Nations; 2017. Available from: https://sustainabledevelopment.un.org/. Accessed 2017 Aug 10.

4. Scheel C. Beyond sustainability. Transforming industrial zero-valued residues into increasing economic returns. J Clean Prod. 2016;131:376-86. doi: 10.1016/j.jclepro.2016.05.018

5. Surie G. Creating the innovation ecosystem for renewable energy via social entrepreneurship: Insights from India. Technol Forecast Soc Change. 2017;121:184-95.

6. REN21. Renewables: 2019: Global Status Report. Paris (France): REN21; 2019. Available from: https:/www.ren21.net/wp-content/uploads/2019/05/ gsr 2019 full report en.pdf. Accessed 2019 Oct 17.

7. MITSloan; BCG. The Innovation Bottom Line. In: Research Report Winter 2013. Boston (MA, US): MITSloan Management Review and the Boston Consulting Group (BCG); 2013. Available from: https://www.bcg.com/documents/file126806.pdf. Accessed 2017 Oct 23. 
8. McDonough W, Braungart M. Upcycling: Beyond Sustainability. New York (NY, US): North Point Press; 2010.

9. United Nations. Sustainable Development Goals. New York (NY, US): United Nations; 2015. Available from: https://www.un.org/sustainabledevelopment/ sustainable-development-goals/. Accessed 2018 Jul 26.

10. Prahalad CK. Bottom of the Pyramid as a source of breakthrough innovations. J Prod Innov Manag. 2012;29(1):6-12.

11. International Energy Agency (IEA). World Energy Outlook 2018. Executive Summary. Paris (France): OECD/IEA; 2018. Available from: https://webstore.iea.org/download/summary/190?fileName=English-WEO2018-ES.pdf. Accessed 2019 Oct 17.

12. Forbes. Modi Announces “ $100 \%$ Village Electrification”, But 31 Million Indian Homes Are Still In The Dark. Forbes. 2018 May 7. Available from: https://www.forbes.com/sites/suparnadutt/2018/05/07/modi-announces-100village-electrification-but-31-million-homes-are-still-in-the-dark/\#1c8ee2b263ba. Accessed 2019 Oct 18.

13. Forbes. Report: India Lifted 271 Million People Out of Poverty In a Decade. Forbes. 2019 July 12. Available from: https://www.forbes.com/sites/ niallmccarthy/2019/07/12/report-india-lifted-271-million-people-out-ofpoverty-in-a-decade-infographic/\#51bc91b72284. Accessed 2019 Oct 18.

14. Ashton WS. The Structure, Function and Evolution of a Regional Industrial Ecosystem. J Ind Ecol. 2009;13(2):228-46. doi: 10.1111/j.15309290.2009.00111.x

15. Iansiti M, Richards GL. The information technology ecosystem: Structure, health and performance. Antitrust Bull. 2006;51(1):77-110.

16. McDonough W, Braungart M. Cradle to Cradle: Remaking the way we make things. New York (NY, US): Farrar, Straus and Giroux; 2002.

17. Boons FAA, Baas LW. Types of industrial ecology: The problem of coordination. J Clean Prod. 1997;5(1-2):79-86. https://doi.org/10.1016/S09596526(97)00007-3

18. Chertow MR. “Uncovering” Industrial Symbiosis. J Ind Ecol. 2007;11(1):11-30.

19. Yin RK. Case Study Research: Design and Methods. 4th ed. Thousand Oaks (CA, US): Sage; 2009.

20. WCED. Our common future. Report of the World Commission on Environment and Development. New York (NY, US): United Nations; 1987. Available from: https://sustainabledevelopment.un.org/content/documents/ 5987our-common-future.pdf. Accessed 2019 Nov 3.

21. Pearce DW, Atkinson G. Measuring sustainable development. Ecodecision. 1993b;9:64-6.

22. Pearce DW, Atkinson G. Capital Theory and Measurement of Sustainable Development: An Indicator of Weak Sustainability. Ecol Econ. 1993a;8:103-8.

23. Van Den Bergh JM, Truffer B, Kallis G. An introduction to environmental innovation and societal transitions. Environ Innov Soc Trans. 2011;1:1-23.

24. Edquist C. Systems of innovations: Perspectives and Challenges. In: Fagerberg J, Mowery DC, Nelson RR, editors. Oxford Handbook of Innovation. Oxford (UK): Oxford University Press; 2005. p. 181-208. 
25. Tukker A, Charter M, Vezzoli C, Sto E, Andersen MM. System Innovation for Sustainability 1: Perspectives on Radical Changes to Sustainable Consumption and Production. Sheffield (UK): Greenleaf; 2008.

26. Truffer B, Coenen L. Environmental Innovation and Sustainability Transitions in Regional Studies. Region Stud. 2012;46(1):1-21.

27. Freeman $\mathrm{C}$. Technological infrastructure and international competitiveness. Draft paper submitted to the OECD Ad hoc group on Science, technology and competitiveness. August 1982. Mimeo. Later published as: Freeman C. Technological infrastructure and international competitiveness. Ind Corp Change. 2004;13:540-52.

28. Lundvall B. NISs and Globalization. In: The Learning Economy and the Economics of Hope. London (UK): Anthem Press; 2016.

29. Lundvall B, editor. National Systems of Innovation: Toward a Theory of Innovation and Interactive Learning. London (UK): Anthem Press; 2010.

30. Nelson RR. National Innovation Systems. New York (NY, US): Oxford University Press; 1993.

31. Miyazaki K, Islam N. Nanotechnology systems of innovation-An Analysis of industry and academia research activities. Technovation. 2007;27:661-75.

32. Hekkart MP, Suurs RA, Negro SO, Kuhlmann S, Smits RE. Functions of innovation systems: A new approach for analyzing technological change. Techol Forecast Soc Change. 2007;74:412-32.

33. Markard J, Raven R, Truffer B. Sustainability transitions: An emerging field of research and its prospects. Res Policy. 2012;41:955-67.

34. Geels FW, Schot J. Typology of sociotechnical transition pathways. Res Policy. 2007;36:399-417.

35. Zhu J, Ruth M. Exploring the resilience of industrial ecosystems. J Environ Manag. 2013;122:65-75.

36. Odum EP. The Strategy of Ecosystem Development. Science. 1969;164(3877):262-70.

37. Dunn BC, Steinemann A. Industrial ecology for sustainable communities. J Environ Plan Manag. 1998;41:661-72.

38. Baas LW, Boons FA. An industrial ecology project in practice: Exploring the boundaries of decision-making levels in regional industrial systems. J Clean Prod. 2004;12(8-10):1073-85.

39. Chertow MR, Ehrenfeld J. Organizing self-organizing systems: toward of theory of industrial symbiosis. J Ind Ecol. 2012;16:13-27.

40. Gibbs D, Deutz P, Proctor A. Industrial ecology and eco-industrial development: a potential paradigm for local and regional development? Region Stud. 2005;39:171-83.

41. Koh SCL, Gunasekaran A, Morris J, Obayi R, Ebrahimi SM. Conceptualizing a circular framework of supply chain resource sustainability. Int J Operat Prod Manag. 2017;37(10):1520-40.

42. Besiou M, Van Wassenhove LN. Addressing the challenge of modeling for decision-making in social responsible operations. Prod Operat Manag. 2015;24(9):1290-401. 
43. Schumpeter JA. The Theory of Economic Development: An Inquiry into Profits, Capital, Credit, Interest, and the Business Cycle. Cambridge (MA, US): Harvard University Press; 1934.

44. Kirzner IM. Competition and Entrepreneurship. Chicago (IL, US): University of Chicago Press; 1973.

45. Baumol WJ. Entrepreneurship: Productive, Unproductive, and Destructive. J Politic Econ. 1990;98(5):893-921.

46. Boettke PJ, Piano E. Baumol's productive and unproductive entrepreneurship after 25 years. J Entrepreneurship Public Policy. 2016;5(2):130-44.

47. Klein PG, Mahoney JT, McGahan AM, Pitelis CN. Toward a theory of public entrepreneurship. Eur Manag Rev. 2010;7:1-15.

48. Baumol WJ, Litan RE, Schramm CJ. Good Capitalism, Bad Capitalism, and the Economics of Growth and Prosperity. New Haven (US): Yale University Press; 2007.

49. Ahlstrom D, Ding Z. Entrepreneurship in China: An overview. Int Small Bus J. 2014;32(6):610-8.

50. Audretsch DB, Keilbach MC, Lehman EE. Entrepreneurship and Economic Growth. New York (US): Oxford University Press; 2006.

51. Sachs JD. Common Wealth: Economics for a Crowded Planet. New York (US): The Penguin Press; 2008.

52. Hahn R. The Ethical Rational of Business for the Poor-Integrating the Concepts Bottom of the Pyramid, Sustainable Development, and Corporate Citizenship. J Bus Ethics. 2009;84(3):313-24.

53. Dacin PA, Dacin MT, Matear M. Social entrepreneurship: Why we don't need a new theory and how we move forward from here. Acad Manag Perspect. 2010;24(3):37-57.

54. Aoyagi C, Ganelli G. Asia’s quest for inclusive growth revisited. J Asian Econ. 2015;40:29-46.

55. OECD. Focus on Inequality and Growth-December 2014. Paris (France): OECD; 2014. Available from: https://www.oecd.org/social/Focus-Inequalityand-Growth-2014.pdf. Accessed 2018 Nov 29.

56. Okun AM. Equality and efficiency: The big trade-off. Washington, D.C. (US): Brookings Institution Press; 1975.

57. Berg AG, Ostry JD. Equality and Efficiency Is there a trade-off between the two or do they go hand in hand? Finance Dev. 2011;48(3):12-5.

58. Ostry JD, Berg A, Tsangarides CG. Redistribution, Inequality and Growth. International Monetary Fund Staff Discussion Note. Washington, D.C. (US): International Monetary Fund; 2014.

59. Sen K. Inclusive growth: When may we expect it? When may we not? Asian Dev Rev. 2014;31(1):136-62.

60. Thorat S, Dubey A. Has growth been socially inclusive during 1993-19942009-10? Econ Polit Weekly. 2012;47(10):43-53.

61. Pierie F, Bekkering J, Benders RMJ, van Gemert WJT, Moll HC. A new approach for measuring the environmental sustainability of renewable energy production systems: Focused on the modelling of green gas production pathways. Appl Energy. 2016;162:131-8. 
62. Terrapon-Pfaff J, Dienst C, König J, Ortiz W. A cross-sectional review: Impacts and sustainability of small-scale renewable energy projects in developing countries. Renew Sustain Energy Rev. 2014;40:1-10.

63. Castillo-Téllez M, Pilatowsky-Figueroa I, López-Vidaña EC, SarracinoMartínez O, Hernández-Galvez G. Dehydration of the red chilli (Capsicum annuum L., costeño) using an indirect-type forced convection solar dryer. Appl Therm Eng. 2017;114:1137-44.

64. Santos-González I, García-Valladares O, Ortega N, Gómez VH. Numerical modeling and experimental analysis of the thermal performance of a Compound Parabolic Concentrator. Appl Therm Eng. 2017;114:1152-60.

65. Sigala M. Customer involvement in sustainable supply chain management: A research framework and implications in Tourism. Cornell Hospit Q. 2014;55(1):76-88.

66. Lee WB. Using Qualitative Methods to Organize Research. Newbury Park (CA, US): Sage Publications; 1999.

67. Eisenhardt KM, Graebner ME. Theory building from cases: opportunities and challenges. Acad Manag J. 2007;50(1):25-32.

68. Yenneti K. The grid-connected solar energy in India: Structures and challenges. Energy Strateg Rev. 2016;11-12:41-51.

69. Miles MB, Huberman AM. Qualitative Data Analysis. Newbury Park (CA, US): Sage Publications; 1994.

70. Eisenhardt KM. Building theories from case study research. Acad Manag Rev. 1989;14(4):532-50.

71. Government of India. Key Highlights of NITI Aayog's Occasional Paper on Eliminating Poverty: Creating Jobs and Strengthening Social Programs. New Delhi (India): NITI Aayog, Government of India; 2018. Available from: https://www.niti.gov.in/writereaddata/files/Summary eliminating_poverty.pdf. Accessed 2018 Nov 29.

72. Department of Science and Technology. Annual Report 2017-2018. New Delhi (India): Department of Science and Technology, Government of India; 2018. Available from: https://drive.google.com/file/d/1IPKUdbSx0Da2Zi ufzC4uT3jCFzPred/view. Accessed 2018 Jul 18.

73. Iacopoli L, Brunori G, Rovai M. Endogenous Development and the Agroindustrial District. In: Van Der Ploeg JD, Van Dijk G, editors. Beyond Modernization: The Impact of Endogenous Rural Development. Assen (The Netherlands): Van Gorcum; 1995.

How to cite this article:

Surie G. Fostering Sustainability through Ecosystems for Renewable Energy in India. J Sustain Res. 2020;2(1):e200010. https://doi.org/10.20900/jsr20200010 